\title{
Animal Rights and the Responsibilities of a Muslim
}

Muhammad Sarwar*

Hafiz Muhammad Tanzeem**

Ahmad Raza***

\begin{abstract}
Islam is the religion of mercy and love. It is based on the great principles of love and compassion, reward, kindness and justice. These golden principles can be seen everywhere in the religious literature of Islam. Be it the Qur'an or the owner of the Qur'an's instructions: Feelings of compassion and mercy will be seen everywhere. Hardness and mischief do not reward. The Holy Prophet was very kind and compassionate towards all creatures. The Prophet (peace and blessings of Allah be upon him) did not tolerate the suffering of even the smallest creatures. Opposes any kind of cruelty to animals. This article reveals the golden teachings of Islam for the oppressed creature of Allah Almighty and the responsibilities of a Muslim in this concern.
\end{abstract}

Keywords: Animal, Rights, Quran, Hadith, Kindness, Cruelty.

\section{Introduction:}

This is the religion of Islam, whose eternal and universal laws, based on the teachings of the Qur'an and Sunnah, not only condemned the cruelty to animals but also imposed regular penalties for violating the rights of animals like humans. Say O Lord of Glory, He is the Seer of all deeds, therefore there is a reward for good deeds and punishment for bad deeds.

Whoever has done an atom's weight of good will see it. And whoever has done an atom's weight of evil will see it. ${ }^{1}$

Explaining the blessed hadith narrated from Hazrat Ibn Umar, according to which the Holy Prophet has cursed the one who harms animals, Allama Ibn Hajar Asqalani wrote:

"The cursing of the Holy Prophet in this way shows that such an act is forbidden"..

"Whoever treats a living being harshly, the Almighty will deal with him harshly on the Day of Resurrection ${ }^{3 \prime \prime}$ ?

Similarly, according to the narration of Hazrat Abdullah bin Umar, a woman was thrown into hell only because she tied a cat. He was not given anything to eat or drink and the cat died in the process. In his commentary on this hadith, Imam al-Nawawi states:

"This hadith means that this act of this woman was Haraam and that is why she will be thrown in hell for her evil deeds. He further writes that from this hadith it is known that killing a cat is forbidden (Haraam) and similarly keeping a cat tied without feeding is also forbidden (Haraam).

The clear meaning of this hadith is that the woman was a Muslim but she will go to hell because of the cat ${ }^{4 \prime \prime}$.

The miracle of Islamic law is that if a person does not abide by the merciful teachings and rules of Islam regarding animals, then he will have to be held accountable to the Almighty for his actions and vice versa. He will treat animals with kindness in the light of God, and he will

* Assistant Professor University of Veterinary and Animal Sciences Lahore.

${ }^{* *}$ Assistant Professor Islamiat, Govt.Graduate College, Daska.

${ }^{* * *}$ Assistant Professor Imperial College of Business Studies, Lahore.

$=$ International Research Journal of Education and Innovation 
be rewarded with them. This is also explained by the Prophetic Hadith, according to which a person will go to Paradise only because he watered a thirsty dog, so forgive him for his past sins because of his kindness. Given When the Holy Prophet was narrating this story to the Companions, the Companions asked: O Messenger of Allah, will we be rewarded for helping the animals? Upon this, Hazrat Muhammad said that every living thing will be rewarded for its help . $^{2}$

Similarly, a prostitute was given a gift just because she had given water to a thirsty dog. This hadith is very important which also states that although this woman may have committed many sins she was forgiven for this good deed ${ }^{6}$.

The beautiful balance of nature and the Qur'an:

Islamic teachings and all sources of growth and guidance in general and the Qur'an, in particular, have strongly emphasized the need to study the beautiful balance of nature as a unity. There are various verses in the Qur'an which invite man to carefully observe and study all the systems of nature.

There seems to be only one purpose behind this call of the Qur'an and that is that as a result of this reflection on nature one can gain knowledge about the creator and operator of this whole system.

Of the aforesaid verses in the Qur'an which are related to the creation of animals, these verses become very important as proof of the existence of a Lord of Glory.

Below are a few of these countless verses.

Likewise, human beings, animals, and livestock come in various colours. From among His servants, the learned fear God. God is Almighty, Oft-Forgiving. ${ }^{7}$ -

Everything we created is precisely measured. ${ }^{8}$.

God knows what every female bears, and every increase and decrease of the wombs. With Him, everything is by measure. ${ }^{9}$ -

Some of the words in the above verses are very important. For example, the word "feminine" refers to a type of feminine pair, whether it relates to humans or animals. In the same way, the word "quantity" is used in the sense of measuring which is used in all such verses. Consistent with its specific purpose.

We spread the earth, and placed stabilizers in it, and in it We grew all things in proper measure. ${ }^{10}$.

Regarding the protection of nature, Hazrat Muhammad said:

"Even when this world is coming to an end (on the Day of Resurrection), if anyone has a palm branch in his hand, he should smell it ${ }^{11 " . .}$

\section{Man Required by the Holy Qur'an:}

Explaining the responsibilities of man as the caliph of Allah, the Qur'an places great emphasis on the creation of mortal qualities which are enshrined in the constitution of man. Justice, generosity, these are the attributes which are the attributes of God that form the basis of the seat on which Allah Almighty has placed man in harmony with the natural laws to establish his kingdom on this earth.

The kingdom of God is not limited to the realm of human beings. The kingdom of God encompasses all creatures and the realm of animals encompasses all. As the Minister of Justice, he was able to administer justice and dignity throughout the kingdom.

$=$ International Research Journal of Education and Innovation $=[113]=$ 
This is what the Qur'an states about its moral philosophy:

So devote yourself to the religion of monotheism - the natural instinct God has instilled in mankind. There is no altering God's creation. This is the true religion, but most people do not know. ${ }^{12}$.

The question that naturally arises is stated by the true religion (Islam). The superiority of (technically implied) man over other species is not due to his physical constitution. As far as reality is concerned, man Many are inferior to animals in one respect.

Muslims are often advised by their reformers to learn from the different species of animals. For example, Hazrat Ali advises that "Become like a bee."

Whatever it eats, it eats cleanly. Whatever it eats, it is sweet. It does not break any branch it sits on.

Man's dominion over other living beings is a headship according to the correct Islamic thought. That is an arrangement under which the ruling class (family) rules over another family with discipline and head-to-head wisdom.

\section{The Qur'an defines this concept in terms of tribal groups:}

There is no animal on land, nor a bird flying with its wings, but are communities like you. We neglected nothing in the Scripture. Then to their Lord they will be gathered. ${ }^{13}$.

\section{The Qur'an further explains what is meant by animal populations:}

Say, "Obey God and obey the Messenger." But if they turn away, then he is responsible for his obligations, and you are responsible for your obligations. And if you obey him, you will be guided. It is only incumbent on the Messenger to deliver the Clarifying Message. ${ }^{14}$.

\section{The Quran and the distribution and classification of animals:}

- The first category includes all kinds of reptiles, insects, and all kinds of reptiles.

- Two-legged: The second category includes birds and mankind.

- Four-legged: The third sex covers all kinds of mammals.

\section{Animals as Ummah in the light of Hadith:}

Hazrat Abu Hurayrah narrates that the Prophet (peace and blessings of Allah be upon him) said: An ant bit one of the Prophets. When they ordered, all the ants' habitat was burned. The Almighty revealed to them: You were bitten by an ant, but you destroyed the entire ummah who were glorifying you ${ }^{15}$.

The following jurisprudence (rule) will apply to the hadith of burning the nests of ants. Any damage or a damage retaliation for damage is forbidden.

Some parents oppress their children and some rulers exploit their subjects. In the same way, there are and will always be people who, under the guise of governing animals, have a formal license to obey all the moral laws that have been enacted to protect animal rights. Can break freely.

Among the people is he whose speech about the worldly life impresses you, and he calls God to witness what is in his heart, while he is the most hostile of adversaries.

When he gains power, he strives to spread corruption on earth, destroying properties and

$=$ International Research Journal of Education and Innovation $=[114]=$ 
lives. God does not like corruption. ${ }^{16}$.

\section{Sir, Syed Ahmad Khan and classification and distribution of animals:}

Sir Syed Ahmad Khan is one of the leaders of Muslims who is unique in his work. He termed the teachings of the Qur'an as by the laws of nature and dared to express other Islamic beliefs in a natural way on which the scholars issued fatwas against him and he was criticized for his "nature".

In any case, Sir Syed Ahmad Khan has presented very precise issues in a very simple way in which modern research seems to be working. When we examine their views on living things, it is clear that they have presented their views on the definition of living things and then on their distribution according to modern scientific research.

There are two types of total bodies you see:

1. Inorganic bodies

2.Organic bodies

Organisms cannot move from their place, while organisms can. The first category includes minerals, salts, iron, and rocks, while organic matter includes plants and animals. You have described in great detail the various features and differences between the two types, which it is not our subject to discuss in full.

The basis of Sir Syed Ahmad Khan's point of view is scientific facts. - His point of view is based on the modern scientific facts of the present day to which he can refer.

"All these matters which we have mentioned are among the matters of research which are well established in the science of zoology and the science of chemistry ${ }^{17 " \prime}$

\section{Synthesis of living Elements:}

According to Sir Syed Ahmad Khan, structures are made up of three elements namely oxygen, hydrogen, and carbon dioxide. In addition to these three elements, animals also have a fourth element called nitrogen. Declare He says:

"We recognize that there are three elements in the body of plants, carbon, oxygen, and hydrogen, and a fourth element in the body of animals is nitrogen ${ }^{18 \prime \prime}$

\section{A Muslim and His Responsibilities:}

According to Islamic teachings, if a person keeps an animal in his possession, he must in any case take care of its needs and basic rights. Every day we hear big painful and sad stories. The most common of these stories is the story of a man who at some point keeps a cat for his own needs. He also protects her and becomes accustomed to eating and drinking. Then all of a sudden this person's heart is full and he throws the cat out of the house and thinks that now the cat will take care of itself or he sometimes doesn't even care what happens to this cat now. Will be. This is gross abuse. Islam forbids such acts and those who do so will have to be held accountable. It is the responsibility of this person to meet the needs of the animals that are living under the shadow of a person and this principle is based on the following verse of the Holy Quran. Also becomes clear:

Worship God, and ascribe no partners to Him, and be good to the parents, and the relatives, and the orphans, and the poor, and the neighbour next door, and the distant neighbour, and the close associate, and the traveller, and your servants. God does not love the arrogant show-

$=$ International Research Journal of Education and Innovation $=[115]=$ 
off. 19 .

There is no shortage of people in our society who think they are the masters and everything here belongs to them so they will use these things as they wish and these things include animals. We also cite the following verse of the Holy Quran in favour of.

Have the people supposed that they will be left alone to say, "We believe," without being put to the test $\mathrm{t}^{20}$ ?

If we talk about their argument, then their argument is proved wrong for several reasons.

The interpretations of this verse make it clear that mankind has been sent to be responsible for the people of the earth and the people of the earth include animals. The same point has been pointed out in Tafseer Jalal al-Din and it has been said that the word "Lakum" makes it clear that all this is made for you, that is, for your benefit so that you may respect them. Similarly, Sheikh Saadi has taken the same meaning from it.

Thus it is clear from these concepts that human beings can use animals as long as they respect them and pay special attention to their needs while respecting their rights.

For any animal to function properly, it must also be equipped with its health and needs. According to Islamic teachings, the Almighty has made man his vicegerent, as the verse states: It is He who made you successors on earth. Whoever disbelieves, his disbelief will recoil upon him. The disbelief of the disbelievers adds only to their Lord's disfavour. The disbelief of the disbelievers adds only to their perdition. ${ }^{21}$.

This verse shows that we are expected to protect the creatures of the Almighty and to protect His creatures in the same way as the four Rightly Guided Caliphs protected the Muslims in the early days.

People on earth, including animals, are being affected by what humans do on earth. The increasing trend of the population in cities, which is leading to the settlement of new areas, is leading to a sharp decline in the number of wild animals, which is also affecting the balance of nature.

Animal populations are also part of our cities and the animals found on earth are largely at the mercy of humans. That is why Muslims in Cairo in the early days of Islamic history were well aware of their responsibilities. They built places for animals to drink water and get food. Even today, several charitable NGOs are working for the welfare and rights of animals in Egypt, which works to feed and treat stray animals.

\section{Universal Declaration of Animal Rights and Welfare:}

A conference of 19 state delegations for animal rights and welfare was held in Manila in March 2003, after which the Star Steering Committee issued a joint statement on November 8 in the light of the recommendations of the member states. The Universal Declaration on Animal Welfare.

Review the key points of the declaration According to the preamble of this declaration, animals have life and they have sensed so they are entitled to be given attention and respect. Animal health is also one of the basic rights and welfare of animals in which veterinarians play a vital role.

Man is interdependent with animals on this planet (Earth). The statement stressed that the World Organization for the Welfare of Animals should develop a system of uniform universal standards for animal rights and welfare. 
All members agreed that the concept of state would include individuals and civil society. Recognition was granted to states that already have animal rights and welfare laws in place.

It was also noted that similar efforts would have to be made to make the animal rights and welfare system more efficient.

It was also acknowledged that good treatment of animals benefits humans.

These basic points are followed by a paragraph on the five basic animal liberties.

"AWARE that the "five freedoms (freedom from hunger, thirst, and malnutrition; freedom from fear and distress; freedom from physical and thermal discomfort; freedom from pain, injury and disease; and freedom to express normal patterns of behaviour)" and the "three Rs (reduction in numbers of animals, refinement of experimental methods and replacement of animals with non-animal techniques)" provide valuable guidance for the use of animals;

RECOGNIZING that the provisions contained in this declaration do not affect the rights of any [state]"22

The five freedoms listed above include freedom from hunger, thirst, and dirty food, freedom from fear and anxiety, freedom from physical and seasonal distress, freedom from pain, wounds, and diseases, and freedom to express one's natural attitudes. The concept of "3Rs" is also included. According to which the reduction in the number of animals in experiments, sophistication in the methods of experiments and non-living methods should be used instead of animals, the principle of this declaration is stated at the end of this declaration as follows: "The welfare of animals shall be a common objective for all [states];

The standards of animal welfare attained by each [state] shall be promoted, recognized, and observed by improved measures, nationally and internationally. [Whilst there are significant social, economic, and cultural differences between societies, each should care for and treat animals humanely and sustainably] [by the principles of the Declaration];

All appropriate steps shall be taken by [states] to prevent cruelty to animals and to reduce their suffering;

Appropriate standards on the welfare of animals are further developed and elaborated such as, but not limited to, those governing the use and management of farm animals, companion animals, animals in scientific research, draught animals, wildlife animals, and animals in recreation" 23

By the principles of this Declaration, animal rights and welfare will be considered a common goal for all member states.

All measures will be taken to prevent cruelty and cruelty to animals. Animal rights and the moral teachings of Islam

Most of the sermons of Islamic scholars consist of sermons and advice against sin. If one of them is interested in choosing a subject concerning many animals, then there is a lot of material in Islamic teachings that he can choose from.

For example, there are unanimous hadiths of Hazrat Muhammad which can provide a very reasonable article for such sermons.

In the following hadiths, Hazrat Muhammad has declared killing animals without any justification as one of the major sins.

According to the Holy Hadith, killing any living being without any reason is considered a grave sin. One of the seven abominable acts that are commanded in both Muslims and Bukhari is to "kill an animal unjustly." 
The Holy Prophet (saw) said:

Whoever kills a bird for no reason, that bird will fly before Allah on the Day of Resurrection and say: 0 Allah, such and such a person has killed me for no reason but has not killed me for any benefit ${ }^{24 \prime}$.

In another narration, the Holy Prophet (PBUH) has declared that killing sins, i.e. polytheism, disobedience of parents as well as destroying any living thing is a grave $\sin ^{25}$. .

Hazrat Muhammad has also imposed punishment and punishment according to the following hadiths.

Translation: It is narrated from Hazrat Abdullah bin Umar that the Prophet (peace and blessings of Allah be upon him) said: A woman was tormented because of a cat. That woman was thrown into hell because of him. He said: (Allah will say to him :) Allah knows best that when you bound him, you neither fed him nor watered him nor left him open that he (himself) ate the insects of the earth. ${ }^{26}$.

In the same way, the Prophet (peace be upon him) told his companions about a man whom Allah had forgiven for saving the life of a dog by giving it water.

Your companions asked you, "O Messenger of Allah, will Allah be rewarded for his kind treatment of animals?" You replied:

Translation: Hazrat Abu Hurayrah narrates that the Prophet (peace and blessings of Allah be upon him) said: A man was on his way when he got very thirsty. He saw a dog panting and licking mud because of thirst. The man thought that this dog was also getting the same condition from thirst which was happening to me (some time ago), so he went down to the well and He filled his socks with water, then grabbed the socks by the mouth and climbed on top of them and watered the dog. Allah accepted his goodness and forgave him. The Companions said: O Messenger of Allah! Is there any reward for us in these animals? He said: There is a reward in every living thing (ie every living animal ${ }^{27}$.

\section{Basic Issues and Problems of Animals:}

There are many types of problems that animals face that can be divided into different levels to understand. The basic problems of animals include the following.

i. Food problems

ii. Housing issues

iii. Problems of living a free life

The growing trend of human populations has created in addition to the above-mentioned basic problems for animals, there are many other problems including continuous violations of animal rights. These violations are presented under the guise of ruthless animals and laws are being enacted in all countries of the world to defend these rights and prevent atrocities against lives. The natural habitats of animals are being rapidly depleted, posing a serious threat to some species of animals. When a forest is cut down from an area, it becomes impossible for the animals living there to get even the necessities, and eventually, the animals lose their lives, leaving only a few species extinct in the balance of the universe. Causes breakdown.

Animal conservation researchers have described the types and forms of cruelty to animals that cause animal problems. Below is a brief description of these cases.

\section{Involuntary Negligence:}

$=$ International Research Journal of Education and Innovation $=[118]=$ 
According to animal rights activists, most animal rights violations do not involve human intent, but such unintentional animal manipulation by humans can lead to many problems. This fact is stated in the report of the American research institute as follows:

"Most reported cases of animal cruelty involve failure to provide adequate food, water, shelter, or veterinary care to one or a few animals. Usually, these are handled by the local animal care and control or humane agencies to educate the offender to provide proper care."28

Criminal negligence in the violation of animal rights

There are some cases of animal rights violations in which human beings are found to be in a state of regular criminal negligence such as (Malicious Neglect). Although such cases are becoming less frequent, their existence cannot be denied. When such cases become more severe, they are called (Intentional Abuse, Torture).

\section{What could be the nature of these cases? It is listed as follows:}

"Animal care and control and law enforcement agencies are reporting a growing number of cases that involve large numbers of animals (often several hundred) kept under extremely poor conditions, often resulting in the death of many animals from disease and starvation. Such cases present substantial challenges for prosecutors due to the large number of animals involved, the possible mental health issues surrounding the defendant (s), and the extremely high recidivism rate seen with this particular offense." 29

\section{Organized Forms of Cruelty to Animals:}

Some of the cases of cruelty to animals are those in which animals are harmed and harmed by regular arrangements. These cases include animal fights which are called (Blood Sports). Whether it's dog fights or cock and bear fights, such fights are banned in most countries of the world. They are not legally permitted, but in developing countries, these battles are fought in defiance of these laws and restrictions. The details of these animal fights have been described by the American research institute as follows.

"Blood Sports" such as dogfighting and cockfighting have been singled out for special attention in the anticruelty laws of the United States and the United Kingdom since their inception in the 19th century. These crimes continue to flourish, often in connection with other offenses. The lucrative and underground nature of these offenses, and the logistical problems of dealing with many defendants and many animals that may be seized as evidence, can present unique challenges to police and prosecutors." 30

A review of the existing laws reveals that the applicability of the laws is very weak due to which violations of these laws are seen day after day. These laws must be made as strict as possible to ensure the protection of animal rights as much as possible.

The following ahadeth describe the principles according to which human beings should use the animals in their service only when they are in dire need, and they should be used for the purpose for which they were created. And their convenience should not be overlooked.

The Holy Prophet (saw) once saw a man sitting on the back of a camel in the bazaar and he said:

The Holy Prophet (peace and blessings of Allah be upon him) said: Beware of making the backs of animals a pulpit. So that you can meet your needs with it-

$=$ International Research Journal of Education and Innovation $=[119]=$ 
Once the Holy Prophet passed by a very weak camel whose stomach was dry and attached to his back. He said: Fear God, be ready to ride on these animals only then (healthy) and set them free to rest ${ }^{31}$ ".

During the journey, Hazrat Muhammad used to give the following advice for the care and convenience of animals.

"When you pass through the green land, pass slowly so that your camels can graze. When you pass through a barren land, pass quickly so that your animals do not become hungry. Do not pitch tents along the way to stay overnight as these are the walking paths of nocturnal creatures 32 "..

Performing the five daily prayers is one of the five most important duties in Islam. In the following hadith, Hazrat Muhammad and one of his companions are telling us that Hazrat Muhammad and his companions, who was traveling with him, used to delay their obligatory prayers. Until they took the load off their riding animals and met their needs.

"When we stayed temporarily, we did not even offer our prayers until we had unloaded the loads on the backs of our camels and met their needs."

Here is a general piece of advice from Hazrat Ali about the animals laden with burdens.

"Treat the loaded animals with kindness. Don't hit them and don't put more burden than they can handle. "

\section{Animal Mental Trauma:}

The care of animals by Islam can be gauged from the fact that it has given importance to mental anguish as much as physical anguish. However, physical abuse also reflects a negative attitude. Islam, as the head of the animal kingdom, imposes upon mankind the responsibility of taking care of all other creatures by the positive philosophy of life. Preventing physical abuse alone is not enough. Equally important is mental anguish.

In this age of scientific research and knowledge, it is no longer difficult to understand that these so-called dumb animals also have regular feelings and responsive emotions.

Dogs, cats, and countless other animals have entered human societies today as pets. They were, in the beginning, untrained wild and ferocious beasts. It was only love and caring for them that won their trust for man and it was the act of man treating and ignoring them that pushed them back to brutality. Given

Hazrat Muhammad personally takes care of his horse, his wife Umm Al-Muminin Hazrat Ayesha's harsh attitude towards her camel and reprimands Hazrat Muhammad for doing so. Forbidding the Holy Prophet (saw) from cutting the hair on the forehead, neck, and tail of the horse. Condemnation of killing and burning animals in their mouths. These ahadeth and many such ahadeth show that this great being, Hazrat Muhammad, fourteen hundred years before today, had realized that even within animals there is a sense of decoration and delicate temperament.

In the following hadith, the anxiety of a bird is taken very seriously as mental anguish. Hazrat Abdul Rahman bin Abdullah has narrated from his father Majid that we were with the Messenger of Allah on a journey. When you went to the toilet, we saw a bird with two babies. We grabbed her baby and started laying on the bird. So when the Holy Prophet came, he said: Who has tormented him because of his children? Her children lay her down. You saw an ant bill that we burned. He said: "Who set it on fire?" We asked (or the Messenger of Allah) we

$=$ International Research Journal of Education and Innovation $=[120]=$ 
did. He said: The torment of the world with fire is not suitable for anyone except the Lord (creator) of fire ${ }^{33 \prime \prime}$.

The scourge of animal cruelty is in some cases even more severe than the cruelty of human beings. Because the hadith is mentioned:

Hazrat Abu Hurayrah narrates that the Holy Prophet (saw) said ${ }^{34}$ :

Instructions are given by Hazrat Imam Izz-ad-Din Al-Salami:

\section{There are two main types of animals:}

i. Wild Animals ii. Pets

The jurists have debated about the rights and care of all kinds of animals. The following is a summary of the instructions given by Imam Izz-ad-Din al-Salami.

1- The owner of a pet should spend everything he needs on his animal (whether it be money, personal time, or hard work) even if the animal is old or sick and there is no one to use it further. Not expected He should spend on such an animal as he spends on a healthy and useful animal.

2- The owner of the animal should not impose more burden on him than he can bear.

3- He should not keep anything with the animal that could harm the animal and cause discomfort to it even if the animal is kept with it is of the same breed or belongs to another sex. Be

4- He should slaughter the animal in a good and proper way, he should not skin the animal and not break its bones until his body is completely cool and all traces of life are removed from his body. Become

5- He must not kill a baby animal in front of his eyes.

6- He should provide separate places (separately) for his animals to rest and drink water and should be clean from such places.

7. It should keep males and females together during their mating season.

8- He should not kill a wild animal with a tool that would break its bones and thus make it unlawful for him to eat ${ }^{35}$.

A research analysis of the above rules and regulations reveals how carefully Islamic jurists have given practical instructions about animals by deducing these Shariah issues and rules.

In Islamic jurisprudence, the rules and etiquettes of animals have been explained in many other ways and by following these rules and etiquettes, the people of Islam have been promised success in this life as well as in the hereafter.

\section{List of Hashim Naji Jazairi and Animal Rights:}

Renowned researcher and jurist Mr. Hashim Naji Jazairi has compiled a list of animal rights in which animal rights have been presented in a very unique way.

This list is summarized below.

1- The face of an animal should not be marked or hit on face because animals also pray and worship Allah Almighty.

2- No animal should be forced to carry more load than it can bear.

3- No animal should be forced to travel beyond its means

4- The back of an animal should not stand on its back or neck.

5- The backs of animals should not be made into pulpits.

$=$ International Research Journal of Education and Innovation 
5- Before filling your stomach, you should think about filling your animal's stomach and feeding it first.

6- Before quenching your thirst, think of your animal's thirst and take great care of it.

7- Unnecessary punishment of animals during training should be avoided.

8- When an animal becomes disobedient, out of control, it should be punished only to the extent necessary ${ }^{36}$.

\section{Animal Factories:}

The use of animals and nature's resources by man is becoming more and more like a contagious disease.

The growing influence of the West has begun to envelop the future roles and destinies of developing countries. Initially, most animal cruelty in these countries was due to individual ignorance and lack of veterinary facilities. While the current oppression is being carried out in a materialistic way, in which both legitimate and illegitimate aggression is being carried out.

Environmentalists today are particularly concerned about agricultural mismanagement. Because the change in our attitudes toward nature has had a profound effect over the last forty years or so.

This concern for nature begins to deepen when it is applied to factory farming and wildlife, all of which depend on the environment. Developing countries that have begun to imitate modern methods of agriculture and enamel husbandry should learn from these mistakes of the West.

\section{Animals and Islam:}

Islamic teachings have taken every possible step to create feelings of love, respect, and sympathy for animals. As it has been stated before that you stopped all the cruelty and aggression against animals that were being done in the time of the Holy Prophet (saw) or before you. The Lord of Glory commanded to pay attention to the neglect of his horse. As stated in the following hadith.

Once the Holy Prophet was seen cleaning the forehead of his horse with his pocket. When asked why you are doing this? So you replied that last night Allah Almighty stopped me from ignoring my horse.

The following hadith forbids the disfigurement of any animal.

The Prophet (peace and blessings of Allah be upon him) said: "Do not cut or tie the hair of a horse's forehead because its politeness is associated with its forehead and not with its neck because with it protects itself and this hair They are used for flying flies. "

The following verses from the Qur'an clearly explain this principle:

Any tearing of the body of any living animal that causes it pain or deformity is against Islamic law.

These verses were revealed in condemnation of secular and superstitious rites, according to which camels, sheep, and goats, which had a certain order and a certain number of children, had a thin hole in their ears and were taken from idols. Was assigned and left open. The Qur'an describes such rituals as evil deeds in the following words:

God did not institute the superstitions of Bahirah, Saibah, Wasilah, or of Hami; but those who

$=$ International Research Journal of Education and Innovation $=[122]=$ 
disbelieve fabricate lies about God-most of them do not understand. ${ }^{37}$.

God has cursed him. And he said, "I will take to myself my due share of your servants. And I will mislead them, and I will entice them, and I will prompt them to slit the ears of cattle, and I will prompt them to alter the creation of God." Whoever takes Satan as a lord, instead of God, has surely suffered a profound loss. ${ }^{38}$

\section{Conclusion:}

1.At present, animals are suffering from many problems and difficulties due to human beings. These problems and difficulties are caused due to the deprivation of their rights. There are countless cases of cruelty to animals that are not mentioned in Islamic law when they are in direct conflict with the basic spirit of Islamic teachings.

2- The main problems of animals are food, shelter, and independent living. Some forms of animal cruelty are unintentional, while others are routinely intentional.

3- Organizations and organizations around the world are working to protect animal rights. Legislation is also being implemented to ensure animal rights. The Islamic world has the best laws for animal rights, but they need to be presented to the United Nations.

4- Under the guise of animal rights, opponents of Islam continue to attack certain rites of Islam. The Islamic world should be offensive instead of defensive in this regard. Al-Azhar University in Egypt is making high-level efforts in this regard.

5- In the present age, the majority of Muslim scholars are not directly aware of the issue of cruelty to animals.

6- Efforts by the Islamic world on animal rights are not enough. There is a solution to every modern problem in the footsteps of Islam, so the people of Islam have to play their role in solving the problems of animals.

\section{References}

1. Az-Zalzlah 99:7-8

2. Asqalani, Ibn Hajar ,Sharh Bukhari, Volume ،1Hadith No 2365, Beirūt: Dār al-Kutub al-Ilmiyyah,

3. Ibid, Hadith No 2366

4. Navwi Imam, Sharh Sahih Muslim, V8,P501, Beirūt: Al-Maktab al-Islāmī

5. Bukhari, Al-Sahih, 168, Hadith No 2195, Beirūt: Dār al-Kutub al-Ilmiyyah,

6. Ibid, Hadith No 3208

7. Al-Fatir 35:28

8. Al-Qamar 54:49

9. Al-Raad 13:8

10. Al-Hajar 15:19

11. Ahmad ibn Hanbal, Abu 'Abd ibn Muhammad Al-Musnan,V3,P184 Egypt, Maktab ul Islami, Beirut, Lebanon:

12. Al-Room 30:30

13. Al-Anaam 6:38

14. Al-Noor 24:45

15. Abu Dawood, Sunan, Kitab al-Adab, Bab fi Qatl al-Dharr, V4,P367,Hadith No 52662, Maktba Rahmania ,Lahore,

16. Al-Baqrah 2:204-205

$=$ International Research Journal of Education and Innovation 
17. Sir Syed Ahmad Khan, Tafsir-ul-Quran,P 642, Lahore, Pakistan: Dost Associates Al-Karim Market Urdu Bazaar, Lahore.

18. Ibid

19. Al-Nisa 4:36

20. Al-Ankboot 29:2

21. Al-Fatir 35:39

22. http://www.worldanimalprotection.cr

23. http://www.worldanimalprotection.cr

24. Nisa'i, Abu Abdul Rahman Ahmad bin Shoaib bin Ali bin Sanan bin Bahr bin Dinar Nasai,Kitab Ul Uodhiya ,Hadith No 4445, Maktat ul Marif,Riyaz ,Saudi Arabia.

25. Bukhari, Al-Sahih, , Hadith No 2851

26. Ibid, Hadith No 2236

27. Hadith No 2234

28. American Prosecutors Research Institute 99 canal center plaza, suite 510 Alexandria, VA 22314 Available at www.nadaa.ogr

29. ibid

30. ibid

31. Hasmi,Majma uzawaid,V8,P196-197,Dar Ul Kutb Ul, Ilmiya,Beriut,Lebnon

32. Muslim, Abu Al-Hussein Ibn Al-Hajjaj bin Muslim bin Ward Qasiri Nishapuri,Kitab Ul Iman,Hadith No 4724, Ahya al Turas ul Arbi, Beirut

33. Ash'ath, Sulayman, Abu Dawud, Al-Sunan, Kitab Ul Jihad ,V3,P55 Hadith No2675, Dar al-Fikr, Beirut, Lebanon

34. Muslim,Kitab ul Bir Wal Silah,V4,P1997,hadith No 2582

35. Izz al-Din Ibn Abd al-Salam al-Salami,P29,Qawaid Ul Ahkaam Fi Masalh il Anaam,Dar ul Taba, Dimaxq,

36. Jazairi, Hashim Naji, Supporting Animals,107-109’ Dar-ul-Salam,

37. Al-Maida 5:103

38. Al-Nisa 4:104-105 